Original paper

\title{
Earthquake and Fire Hazard Risk Perception: A Study on the Emerging Rangpur City of Bangladesh
}

\author{
Md Zakiur Rahman ${ }^{1 *}$, Funda Atun ${ }^{2}$ and Javier Martinez ${ }^{2}$
}

Received: 29/12/2020 / Accepted: 17/06/2021 / Published online: 23/09/2021

\begin{abstract}
Rangpur city is one of the emerging cities in Bangladesh. In 2012, this city upgraded from municipality to city corporation. On the one hand, the city population started to increase; on the other hand, vulnerability to earthquake and fire hazards are increased due to rapid urbanization. Therefore, we investigate the risk perception of earthquake and fire hazards in Rangpur. The purpose of this study is fourfold: (i) to assess the risk perception of earthquake hazards and fire hazards at the household level; (ii) to investigate the influence of demographic and socio-economic factors on the risk perception of each hazard; (iii) to investigate the preparedness for earthquake and fire hazards; and (iv) to propose planning guidelines and policy interventions for the disaster resilience of the Rangpur city focusing on earthquake and fire hazards. We conducted a questionnaire survey with 558 participants and 9 semi-structured interviews in fifteen electoral wards in Rangpur city. Afterward, we analyzed the data in SPSS and ArcMap platforms. The study results show that socio-demographic indicators such as gender, household ownership type, and residential floor are likely to influence citizens' risk perception. We also find that the spatial distribution of risk perception of both hazards is diversified at the electoral ward level. At the same time, we observe that the level of preparedness for both hazards is not satisfactory. Based on the study findings, we recommend a few planning guidelines and policy interventions for disaster resilience in Rangpur city.
\end{abstract}

Keywords: Risk perception, earthquake hazard, fire hazard, disaster resilience, Bangladesh

\footnotetext{
${ }^{1}$ Department of Geography and Environmental Science, Begum Rokeya University, Rangpur, Bangladesh

* Corresponding author Email: mzrahman.brur@gmail.com

2 Department of Urban and Regional Planning and Geo-Information Management (PGM), Faculty of GeoInformation Science and Earth Observation, University of Twente, The Netherlands
} 


\section{INTRODUCTION}

Risk perception is connected with people's willingness to take precautionary actions, and knowing the citizens' perception could guide the government and related organizations to formulate risk reduction policies (Fernandez, Tun, Okazaki, Zaw, \& Kyaw 2018). Apart from that, people take actions according to their priorities and objectives (Norton, Atun, \& Dandoulaki 2015). The success of disaster risk management policies and interventions depends on the level of disaster risk perception and knowledge of the matter at the household level.

There is a paradox that increased risk perception is not always connected to protective measures because numerous contextual factors could influence risk perception, such as the ability to recall past damages and trust in public and related authorities. (Wachinger, Renn, Begg, \& Kuhlicke 2013). Still, people should understand the risk associated with different hazards to take preparedness measures against potential hazards. Moreover, assessing risk perception in a multi-hazard environment is essential in identifying vulnerable individuals' reality with respect to a particular hazard because distinct hazard characteristics influence risk perception (Sullivan-Wiley \& Gianotti 2017).

Psychometric theory and cultural theory are considered the primary theories that can explain risk perception (Shrestha, Sliuzas, \& Kuffer 2018). Appleby-Arnold, Brockdor, Jakovljev, \& Zdravković (2018, p.38) argued - "both living in a disaster-prone area and previous experience of disasters have been found to affect disaster risk perception, but they do not directly translate into an increase of perceived future risks". However, socio-demographic characteristics, such as age, gender, ethnicity, socio-economic status, etc., influence risk perception of numerous hazards (Appleby-Arnold et al. 2018; Fernandez et al. 2018).

It is considered that high population growth could intensify the multi-hazard environment (Sullivan-Wiley \& Gianotti, 2017); thus, the growing cities of Bangladesh are likely exposed to the multi-hazard environment (LGED 2014; RpCC 2019). Therefore, this study investigates the risk perception of earthquake and fire hazards at the household level.

Bangladesh is an Asian country, ranking fifth among the world's disaster-prone countries (Rahman, Ansary, \& Islam 2015). Notably, in Asia, around half of the deaths and disasterrelated damage occurred by earthquakes compared to all natural disasters in the last decades (Kung \& Chen 2012), and Bangladesh is at high risk of a severe earthquake (Rahman et al. 2015). Like many other Bangladeshi cities, Rangpur city does not encounter regular flooding, but this city is vulnerable to earthquakes.

Rangpur city is one of the emerging cities in Bangladesh. In 2012, this city upgraded from municipality to city corporation. Consequently, the city population started to proliferate; in 2012, the total population was 584,448, and in 2017 it was 796,556 (RpCC 2019). At the same time, Bangladesh is divided into three seismic zones (zone 1, $2 \& 3$ ), and Rangpur city is located on the borderline of seismic zone-1 and zone-2 (Ali 1998; Paul \& Bhuiyan 2010; Rahman 2020). Moreover, Rangpur city was the epicenter in some past major earthquakes (Ali 1998). 
Apart from earthquake risk, the cities in Bangladesh often face devastating fire accidents, causing many deaths each year (Burke \& Hammadi 2012; Jones 2010; Safi 2019). Considering the above facts, we planned to carry out this study by selecting 15 electoral wards from the Rangpur City Corporation (RpCC) area (Figure 1). According to our knowledge, this study is the first one that uncovers the fire and earthquake risk perception in Rangpur city. The findings from this study could be helpful for government authorities in formulating planning guidelines and policies. At the same time, the study could be a baseline study for the cities with similar social, cultural, and physical characteristics.

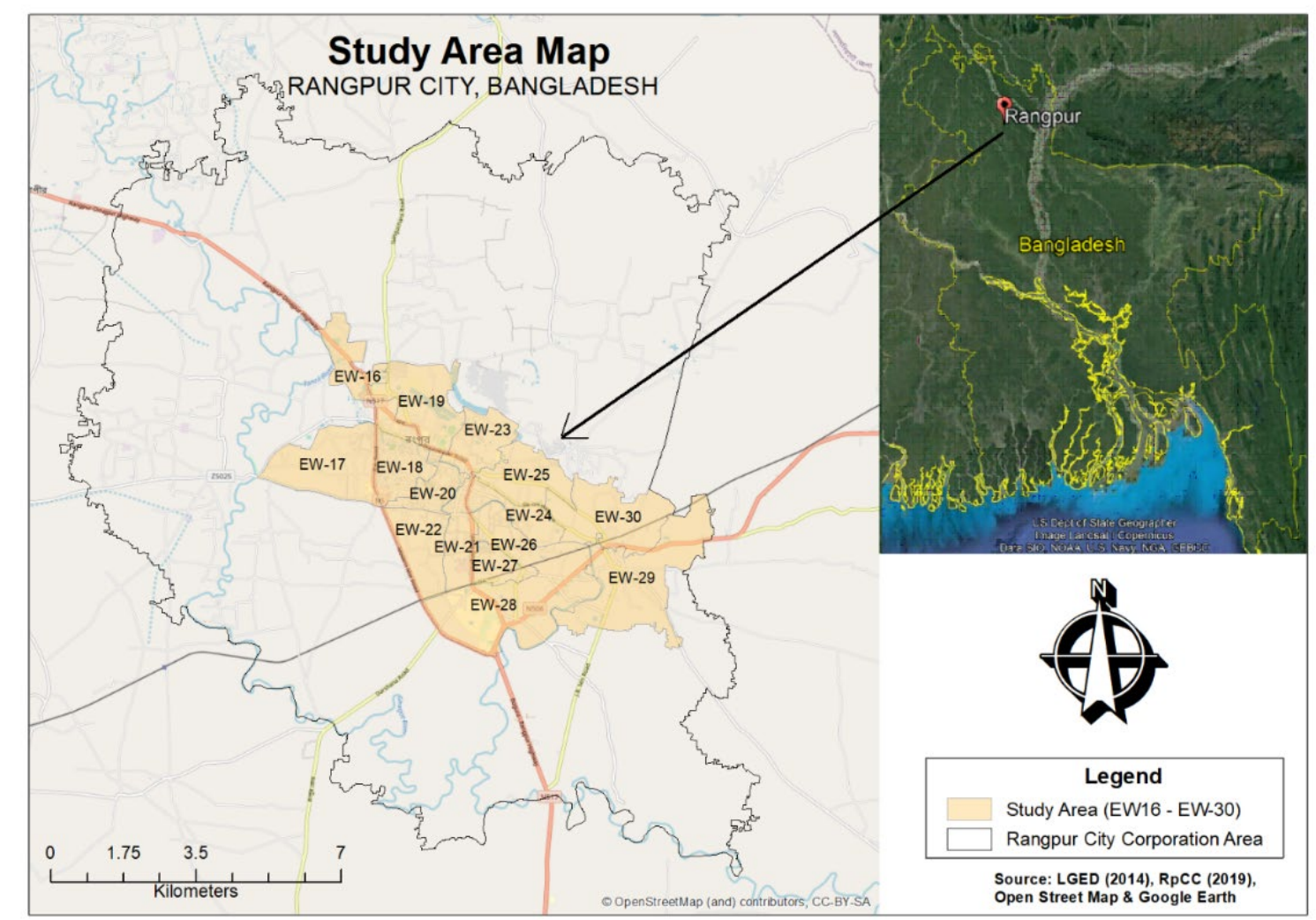

Figure 1. Study area map (Source: LGED, 2014; RpCC, 2019;

Open Street Map, 2000 \& Google Earth, 2020)

The objectives of this study are (i) to assess the risk perception of earthquake hazard and fire hazards at the household level; (ii) to investigate the influence of demographic and socioeconomic factors on the risk perception of each hazard; (iii) to investigate the preparedness for earthquake and fire hazards; and (iv) to propose planning guidelines and policy interventions for the disaster resilience in the Rangpur city focusing on earthquake and fire hazards. 


\section{DATA AND METHODS}

\subsection{Sources of data}

A mixed-method approach (qualitative and quantitative) was adopted to carry out this research. The quantitative aspect of this research includes collecting and statistical analysis of risk perception data and analysis of risk perception dynamics at the electoral ward level. The qualitative approach includes the semi-structured interview with key persons; this helped us understand the results from quantitative analysis and formulate planning guidelines and recommendations.

Thus, we collected primary and secondary data from 15 electoral wards (EW16-EW30) in Rangpur city; primary data were collected from direct field surveys and semi-structured interviews. 558 participants have participated in the questionnaire survey, and 382 samples from the survey were considered for final analysis. We eliminated one hundred ninety-eight samples because the survey duration of those samples was less than eight minutes which seems less reliable for further analysis.

Table 1. List of interviewees and interview duration

Key persons for the semi-structured interview

One of the professors of the Department of Disaster Management, Begum Rokeya University, Rangpur (BRUR)

One of the professors of the Department of Geography and Environmental Science, BRUR

One of the officials of Disaster Management E-learning Center, BRUR

One of the officials of Fire Service and Civil Defence, Rangpur

One of the officials Rangpur City Corporation (RpCC)

One of the professors of the Faculty of Life and Earth Sciences, BRUR

One of the social activists, Rangpur

One of the ward commissioners, RpCC

One of the ward commissioners, RpCC

\section{Interviewee Code}

I-1

$\mathrm{I}-2$

I-4

I-5

I-6

I-7

I-8

I-9

Data from the questionnaire survey provided socio-demographic and risk perception information. At the same time, we conducted 9 semi-structured interviews with key people (Table 1). Apart from the primary data, secondary data (shapefiles) provided the administrative boundaries at different scales (national, district, city corporation, and electoral ward). 


\subsection{Risk Perception Index (RPI)}

To assess the risk perception on earthquake and fire hazards, we adapted a few questions (Table $2 \&$ Table 3 ) from the available literature on earthquake and fire hazard risk perception (Chan et al. 2018; Kung \& Chen 2012; Paul \& Bhuiyan 2010; Shrestha et al. 2018). Two different Risk Perception Indices (RPI) were used to calculate earthquake risk perception (Equation 1) and fire risk perception (Equation 2); both equations were adapted from (Rahman 2020).

Table 2. Indicators, interview questions, and assigned values of earthquake risk perception

\begin{tabular}{|c|c|c|c|c|c|c|}
\hline $\begin{array}{l}\text { Question } \\
\text { Number }\end{array}$ & Indicator & $\begin{array}{l}\text { Interview } \\
\text { Question }\end{array}$ & Scale & $\begin{array}{c}\text { Assigned } \\
\text { Perception } \\
\text { Value }\end{array}$ & \multicolumn{2}{|c|}{ Type } \\
\hline 1 & $\begin{array}{l}\text { Witness of the } \\
\text { previous incident }\end{array}$ & $\begin{array}{l}\text { Did you witness or } \\
\text { experience an } \\
\text { earthquake? }\end{array}$ & $\begin{array}{l}\text { No } \\
\text { Yes }\end{array}$ & $\begin{array}{l}0 \\
1\end{array}$ & & \\
\hline 2 & Future possibility & $\begin{array}{l}\text { Do you agree that a } \\
\text { severe earthquake may } \\
\text { hit your living place? }\end{array}$ & $\begin{array}{l}\text { Strongly disagree } \\
\text { Disagree } \\
\text { Neutral } \\
\text { Agree } \\
\text { Strongly Agree }\end{array}$ & $\begin{array}{l}0 \\
0.25 \\
0.50 \\
0.75 \\
1\end{array}$ & & \\
\hline 3 & $\begin{array}{l}\text { Effect on } \\
\text { personal life and } \\
\text { family }\end{array}$ & $\begin{array}{l}\text { Do you agree that the } \\
\text { earthquake will affect } \\
\text { you and your family? }\end{array}$ & $\begin{array}{l}\text { Strongly disagree } \\
\text { Disagree } \\
\text { Neutral } \\
\text { Agree } \\
\text { Strongly Agree }\end{array}$ & $\begin{array}{l}0 \\
0.25 \\
0.50 \\
0.75 \\
1\end{array}$ & శี & \\
\hline 4 & $\begin{array}{l}\text { Perceived risk of } \\
\text { property damage }\end{array}$ & $\begin{array}{l}\text { Do you agree that the } \\
\text { earthquake may result in } \\
\text { damage to your property? }\end{array}$ & $\begin{array}{l}\text { Strongly disagree } \\
\text { Disagree } \\
\text { Neutral } \\
\text { Agree } \\
\text { Strongly Agree }\end{array}$ & $\begin{array}{l}0 \\
0.25 \\
0.50 \\
0.75 \\
1\end{array}$ & 这 & $\begin{array}{l}.0 \\
0 \\
0 \\
0 \\
0 \\
0 \\
2\end{array}$ \\
\hline 5 & $\begin{array}{l}\text { Perceived risk of } \\
\text { death }\end{array}$ & $\begin{array}{l}\text { Do you agree that the } \\
\text { earthquake may result in } \\
\text { death and injury? }\end{array}$ & $\begin{array}{l}\text { Strongly disagree } \\
\text { Disagree } \\
\text { Neutral } \\
\text { Agree } \\
\text { Strongly Agree }\end{array}$ & $\begin{array}{l}0 \\
0.25 \\
0.50 \\
0.75 \\
1\end{array}$ & & $\frac{y}{a n}$ \\
\hline 6 & Fearfulness & $\begin{array}{l}\text { How fearful are you } \\
\text { about a possible } \\
\text { earthquake? }\end{array}$ & $\begin{array}{l}\text { Not fearful } \\
\text { Little fearful } \\
\text { Moderate fearful } \\
\text { Highly fearful }\end{array}$ & $\begin{array}{l}0 \\
0.33 \\
0.66 \\
1\end{array}$ & & \\
\hline 7 & $\begin{array}{l}\text { Prior } \\
\text { arrangement of } \\
\text { first aid and } \\
\text { emergency kits } \\
\text { Presence of } \\
\text { emergency exit }\end{array}$ & $\begin{array}{l}\text { Do you have any first aid } \\
\text { kits or any emergency } \\
\text { kits to face earthquake } \\
\text { occurrence? } \\
\text { Do you have any } \\
\text { emergency exits for such } \\
\text { type of situation? }\end{array}$ & $\begin{array}{l}\text { No } \\
\text { Yes }\end{array}$ & $\begin{array}{l}0 \\
1\end{array}$ & $\begin{array}{l}0 \\
0 \\
0 \\
0 \\
0 \\
0 \\
0 \\
0 \\
0\end{array}$ & \\
\hline
\end{tabular}


Table 3. Indicators, interview questions, and assigned values of fire risk perception

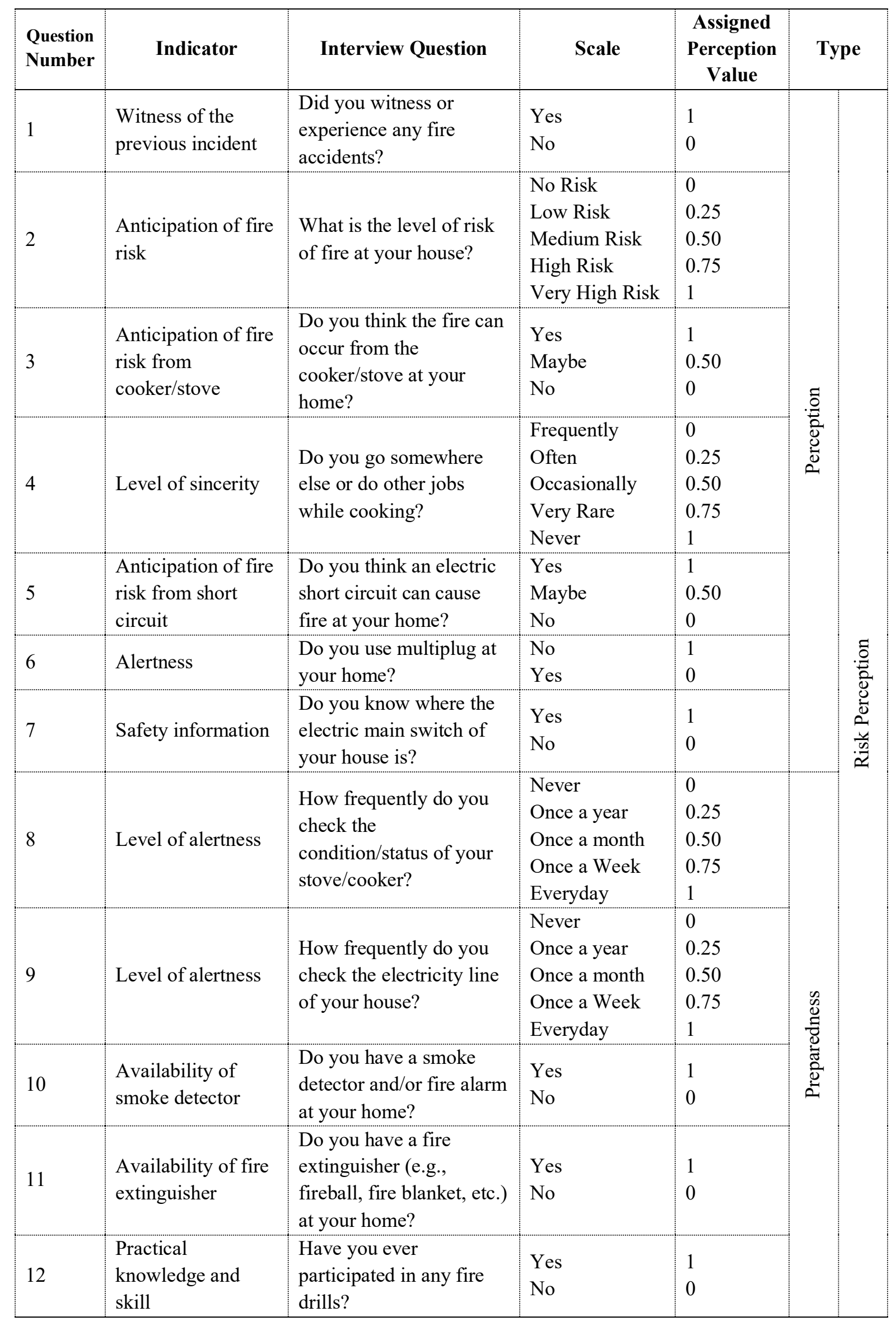




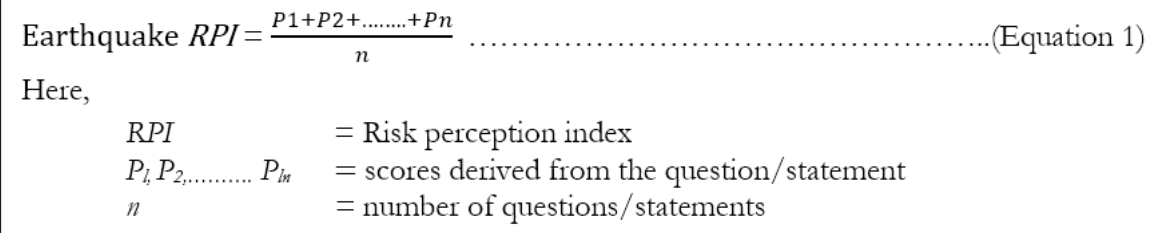

Figure 2. Equation 1: Earthquake Risk Perception Index (Rahman 2020).

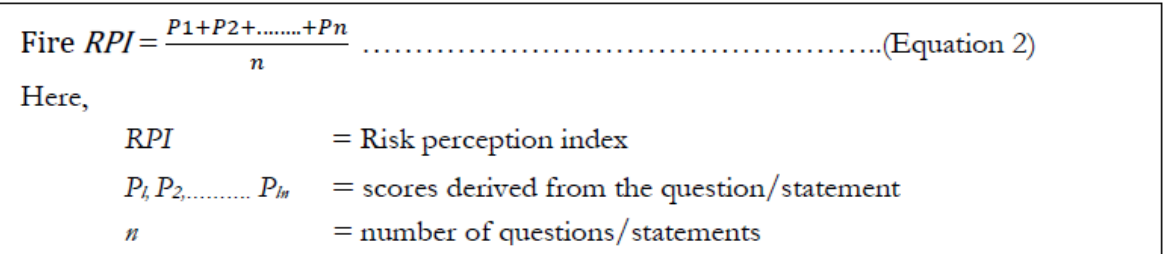

Figure 3. Equation 2: Earthquake Risk Perception Index (Rahman 2020).

\subsection{Data analysis}

Statistical methods were employed to analyze the data. Descriptive analysis was carried out to understand the respondent's anticipation/opinion on different aspects of earthquake and fire hazards. Box and whisker plots were also used to investigate the influence of demographic and socio-economic factors on each hazard's risk perception. Correlation analysis and t-test were carried out to validate the relationship between socio-demographic factors and the hazard's risk perception.

\section{RESULTS}

\subsection{Earthquake risk perception (ERP)}

\subsubsection{Respondent's anticipation/opinion on different aspects of earthquake hazard}

Respondent's anticipations/opinions on various aspects of earthquake hazard are shown in Table 4. The first question was related to the experience of previous earthquake events. $99 \%$ of respondents have experienced at least one earthquake. Among the respondents, only 3\% strongly disagreed that a severe earthquake may hit their living place. On the other hand, $48 \%$ of the respondents agreed or strongly agreed about the possibility of the occurrence. Similarly, more than $50 \%$ of respondents agreed or strongly agreed that a possible earthquake could affect them and their family members; however, $7 \%$ of respondents disagreed or strongly disagreed in this regard. 
Table 4. Respondent's anticipation/opinion on different aspects of earthquake hazard

\begin{tabular}{|c|c|c|c|}
\hline \multirow{2}{*}{ Questions } & \multirow{2}{*}{ Opinion/anticipation } & \multicolumn{2}{|c|}{ Respondents } \\
\hline & & Number $(n)$ & Percentage (\%) \\
\hline \multirow{2}{*}{$\begin{array}{l}\text { Did you witness or experience an } \\
\text { earthquake? }\end{array}$} & Yes & 380 & 99 \\
\hline & No & 2 & 1 \\
\hline \multirow{5}{*}{$\begin{array}{l}\text { Do you agree that a severe earthquake } \\
\text { may hit your living place? }\end{array}$} & Strongly disagree & 10 & 3 \\
\hline & Disagree & 42 & 11 \\
\hline & Neutral & 147 & 38 \\
\hline & Agree & 128 & 34 \\
\hline & Strongly Agree & 55 & 14 \\
\hline \multirow{5}{*}{$\begin{array}{l}\text { Do you agree that an earthquake could } \\
\text { affect you and your family? }\end{array}$} & Strongly disagree & 3 & 1 \\
\hline & Disagree & 23 & 6 \\
\hline & Neutral & 123 & 32 \\
\hline & Agree & 126 & 33 \\
\hline & Strongly Agree & 107 & 28 \\
\hline \multirow{5}{*}{$\begin{array}{l}\text { Do you agree that an earthquake may } \\
\text { result in damage to your property? }\end{array}$} & Strongly disagree & 2 & 1 \\
\hline & Disagree & 12 & 3 \\
\hline & Neutral & 115 & 30 \\
\hline & Agree & 126 & 33 \\
\hline & Strongly Agree & 127 & 33 \\
\hline \multirow{5}{*}{$\begin{array}{l}\text { Do you agree that an earthquake may } \\
\text { result in death and injury? }\end{array}$} & Strongly disagree & 1 & 0 \\
\hline & Disagree & 20 & 5 \\
\hline & Neutral & 101 & 26 \\
\hline & Agree & 120 & 31 \\
\hline & Strongly Agree & 140 & 37 \\
\hline \multirow{4}{*}{$\begin{array}{l}\text { How fearful are you about a possible } \\
\text { earthquake? }\end{array}$} & Not fearful & 58 & 15 \\
\hline & Little fearful & 188 & 49 \\
\hline & Moderate fearful & 75 & 20 \\
\hline & Highly fearful & 61 & 16 \\
\hline
\end{tabular}

\subsubsection{Analysis of earthquake risk perception by socio-demographic factors}

This section analyses how risk perception of earthquake hazards changes with different socio-demographic factors. Figure 4 and 'Appendix' show the changing nature of earthquake risk perception with the variation of socio-demographic factors.

\section{Earthquake risk perception by gender}

The risk perception of earthquake hazards slightly varies with gender. Female respondents have a higher risk perception than male respondents (Figure 4A). The women's median risk 
perception value is 0.70 , while the median value is 0.66 for the men. The interquartile range is also higher for women. The t-test also shows that women have higher ERP than men $(p=0.007)$.

\section{Earthquake risk perception by age group}

The ERP value also changes within the different age groups. However, the changing pattern is not linear, and the ' $p$ ' value for the ANOVA test is 0.952 , which is not statistically significant. Respondents between 18-24 years old had the highest ERP value (mean value is 0.67, and the median value is 0.70), while the elderly (59 years + ) has the lowest ERP (median, 0.65). However, the lowest ERP median value (0.67) was calculated in the second age group (Figure 4B).

\section{Earthquake risk perception by education level}

The education level did not show significant changes in the ERP (' $p$ ' value from ANOVA is 0.595). However, respondents with a bachelor's or higher degree showed higher risk perception based on the median ERP value (0.70) (Figure 4C).

\section{Earthquake risk perception by profession}

Statistically significant diverse ERPs were observed among the professional group (ANOVA shows that $p<0.01)$. The housewives and government service holders had the highest ERP (median values are 0.72 and 0.71 , respectively). On the other hand, daily wage earners had the lowest ERP (median value is 0.56). However, farmers had the lowest ERP based on the mean value (0.59), while the mean ERP value for the daily wage earners was 0.60 (Figure 4D).

\section{Earthquake risk perception by monthly household income}

Figure 4E shows that the lower-income group had a lower ERP score, and the higher-income group had a higher ERP score (' $p$ ' value from ANOVA is 0.004). However, the fourth income group (30001-40000 in BDT) did not follow the risk perception trend of other income groups. This group has a lower ERP than the first two income groups.

\section{Earthquake risk perception by household type}

In general, the ERP by household type reveals that the better the household construction type, the higher the ERP (Figure 4F). The 'Jhupri'3 houses had the highest ERP value based on both mean and median values. The reason behind this result could be the outlier and the low number of samples ( $n=11)$ of 'Jhupri.' After eliminating the outlier, 'Jhupri' shared the highest ERP with 'Pucca' ${ }^{1}$ house (based on the mean value that is 0.68 ).

\section{Earthquake risk perception by a household storey}

Figure 4G shows that multi-storey households likely have slightly higher earthquake risk perception than single-storey households. The mean and median ERP values of single-storey households are 0.66 and 0.67 , respectively. On the other hand, both the mean and median ERP value of multi-storey households are 0.68 . However, the t-test did not find any significant relation with the ERP $(p=0.294)$.

\footnotetext{
${ }^{3}$ Jhupri (shacks); made of jute sticks, tree leaves, jute sacks etc. Pucca (permanent, life span over 25 years); will walls of bricks and roofs of concrete.” (Source: https://en.banglapedia.org/index.php?title=Housing)
} 

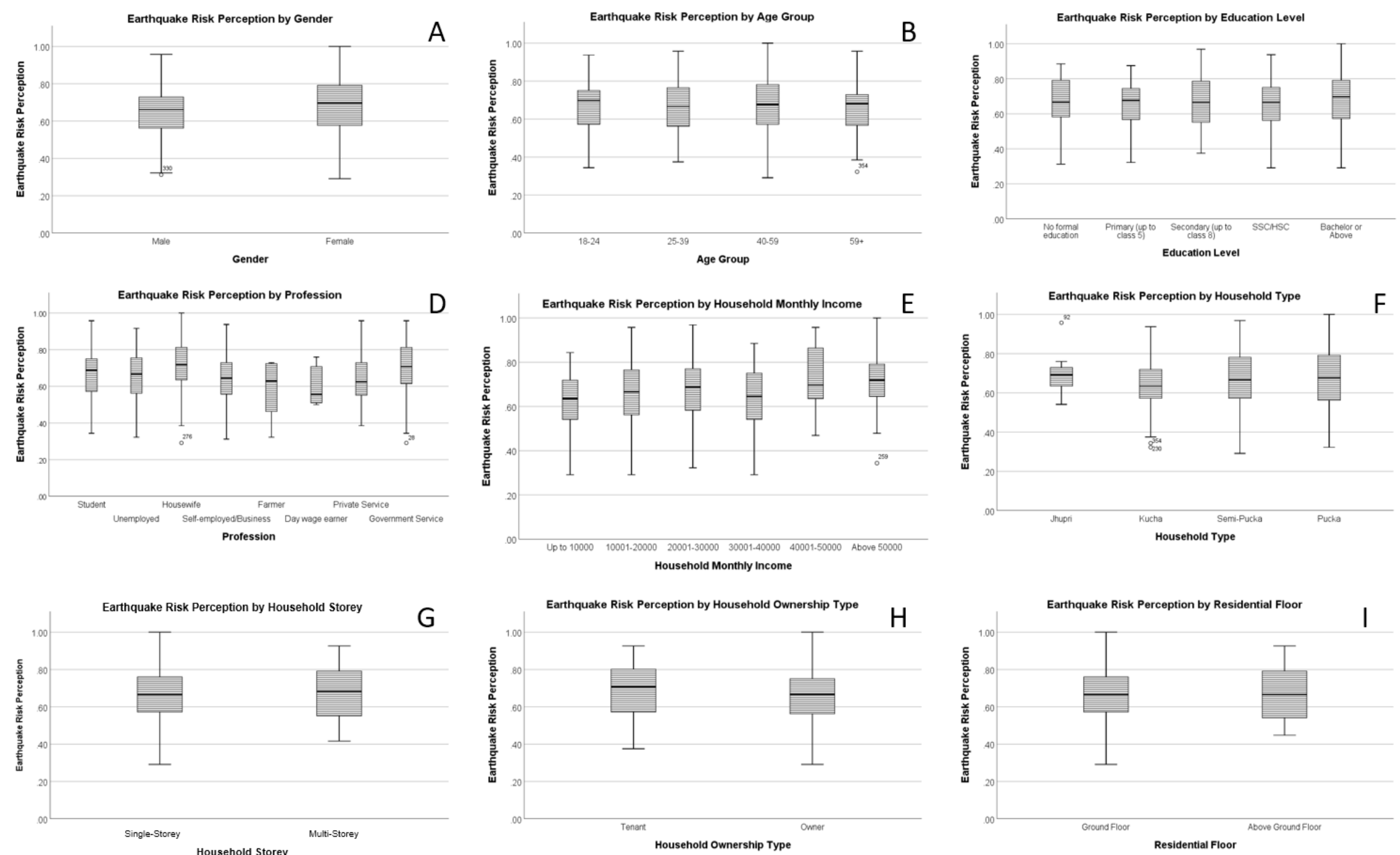

Figure 4. Earthquake risk perception and socio-demographic factors 


\section{Earthquake risk perception by household ownership type}

It was observed that the tenants have higher ERP than the house owners. The median ERP value of tenants is 0.71 , where the median ERP value of house owners is 0.67 (Figure $4 \mathrm{H}$ ). Besides, the t-test also showed that the tenants have a higher risk perception of earthquake hazards than the house owners $(p=0.027)$.

\section{Earthquake risk perception by residential floor}

The residential floor had no significant impact on the ERP (based on the median value). Ttest also failed to show significant relations $(p=0.699)$. However, ground floor residents' mean ERP value is lower than the respondents living above the ground floor (Figure 4I).

\subsubsection{Earthquake risk perception dynamics at electoral ward level}

Table 5 shows the earthquake risk perception dynamics at the electoral ward (EW) level. EW-20 has the highest earthquake risk perception, and the risk perception score is 0.77 . On the other hand, EW-18 has the lowest risk perception of earthquake hazard; the risk perception score is 0.56 .

Table 5. Earthquake risk perception at electoral ward level

\begin{tabular}{ccc}
\hline $\begin{array}{c}\text { Electoral Ward } \\
\text { Number }\end{array}$ & $\begin{array}{c}\text { Earthquake Risk } \\
\text { Perception Score }\end{array}$ & $\begin{array}{c}\text { Rank (high to low risk } \\
\text { perception) }\end{array}$ \\
\hline EW-20 & 0.7711 & 1 \\
EW-23 & 0.7708 & 2 \\
EW-16 & 0.7320 & 3 \\
EW-27 & 0.7189 & 4 \\
EW-30 & 0.7064 & 5 \\
EW-17 & 0.6818 & 6 \\
EW-21 & 0.6747 & 7 \\
EW-28 & 0.6557 & 8 \\
EW-19 & 0.6524 & 9 \\
EW-25 & 0.6434 & 10 \\
EW-26 & 0.6242 & 11 \\
EW-22 & 0.6105 & 12 \\
EW-29 & 0.5980 & 13 \\
EW-24 & 0.5930 & 14 \\
EW-18 & 0.5606 & 15 \\
\hline
\end{tabular}




\subsubsection{Preparedness on earthquake hazard at the household and electoral ward level}

Figure 5 shows overall preparedness for earthquake hazards in RpCC. $47 \%$ of respondents have an emergency first-aid kit at home (Figure 5A). At the same time, 59\% of households have an emergency exit. No household has an emergency kit in the most vulnerable area, EW18. Moreover, households of EW-18 have the least percentage of emergency exits (Figure 5B). On the other hand, $89 \%$ of households of EW-20 have an emergency first-aid kit, and $84 \%$ of households of EW-16 have an emergency exit. It is worth mentioning again that $99 \%$ of the respondents have experienced an earthquake.

Availability of First-aid Kit at Home (A)

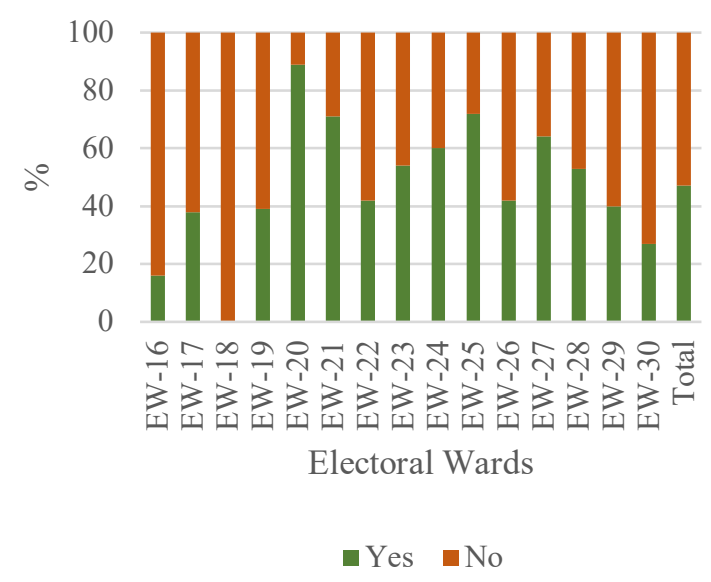

Availability of Emergency Exit (B)

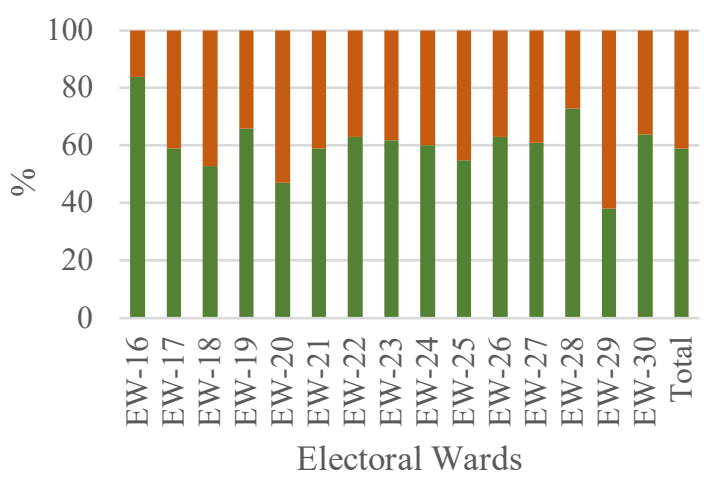

- Yes $\quad$ No

Figure 5. Availability of first-aid kit at home (A) and availability of emergency exit at home (B).

\subsection{Fire risk perception (FRP)}

\subsubsection{Respondent's anticipation/opinion on different aspects of earthquake hazard}

Respondent's anticipations/opinions on different aspects of fire hazard are shown in Table 6. Among 382 respondents, $81 \%$ of respondents witnessed/experienced the fire hazard. $70 \%$ of respondents anticipated that fire risk is less likely to affect their households. On the other hand, only $6 \%$ of respondents think there is a high and very high risk of fire affecting their household.

More than half of the surveyed population (53\%) assume that fire can occur from the household's cooker or stove, while $15 \%$ responded as 'no', and $31 \%$ replied as 'maybe'. Among the respondents, $16 \%$ never leave the kitchen until the cooking is finished and the cooker is switched off. However, a large number of respondents (43\%) replied that they frequently or often leave the kitchen during cooking activities to attend to another task.

A relatively large number of respondents $(60 \%)$ agreed that a short-circuit or electric disturbance might result in a fire at home. In comparison, 30\% of the respondents said 'maybe' an electric short-circuit could be the cause of fire at home and, 10\% denied the possibility. 
However, $93 \%$ of respondents knew the location of the electric main switch, which could be switched off during such an event. Besides, $68 \%$ of households use multiplug to connect their electric appliances though electric short-circuit could occur.

Table 6. Respondent's anticipation/opinion on different aspects of fire hazard

\begin{tabular}{|c|c|c|c|}
\hline \multirow{2}{*}{ Question } & \multirow{2}{*}{$\begin{array}{c}\text { Opinion/ } \\
\text { anticipation }\end{array}$} & \multicolumn{2}{|c|}{ Respondents } \\
\hline & & Number $(n)$ & Percentage (\%) \\
\hline \multirow{2}{*}{$\begin{array}{l}\text { Did you witness or experienced any } \\
\text { fire accidents? }\end{array}$} & Yes & 309 & 81 \\
\hline & No & 73 & 19 \\
\hline \multirow{5}{*}{$\begin{array}{l}\text { What is the level of risk of fire at } \\
\text { your house? }\end{array}$} & No Risk & 104 & 27 \\
\hline & Low Risk & 164 & 43 \\
\hline & Medium Risk & 93 & 24 \\
\hline & High Risk & 15 & 4 \\
\hline & Very High Risk & 6 & 2 \\
\hline \multirow{3}{*}{$\begin{array}{l}\text { Do you think the fire can occur } \\
\text { from the cooker/stove at your } \\
\text { home? }\end{array}$} & Yes & 204 & 53 \\
\hline & Maybe & 120 & 31 \\
\hline & No & 58 & 15 \\
\hline \multirow{5}{*}{$\begin{array}{l}\text { Do you go somewhere else or do } \\
\text { other jobs while cooking? }\end{array}$} & Frequently & 104 & 27 \\
\hline & Often & 62 & 16 \\
\hline & Occasionally & 98 & 26 \\
\hline & Very Rare & 58 & 15 \\
\hline & Never & 60 & 16 \\
\hline \multirow{3}{*}{$\begin{array}{l}\text { Do you think an electric short } \\
\text { circuit can cause fire at your home? }\end{array}$} & Yes & 230 & 60 \\
\hline & Maybe & 116 & 30 \\
\hline & No & 36 & 10 \\
\hline \multirow{2}{*}{$\begin{array}{l}\text { Do you know where the electric } \\
\text { main switch of your house is? }\end{array}$} & Yes & 357 & 93 \\
\hline & No & 25 & 7 \\
\hline \multirow{2}{*}{$\begin{array}{l}\text { Do you use multiplug at your } \\
\text { home? }\end{array}$} & Yes & 260 & 68 \\
\hline & No & 122 & 32 \\
\hline
\end{tabular}

Source: Fieldwork (January 2020)

\subsubsection{Analysis of fire risk perception by socio-demographic factors}

In this section, we analyzed how fire risk perception changes with different sociodemographic factors. Figure 6 shows how fire risk perception changes with different sociodemographic factors.

\section{Fire risk perception by gender}

Figure 6A shows that fire risk perception also varies with gender, as does earthquake risk perception. However, here the observation is opposite to ERP. The median line shows that females have lower risk perception than males. Moreover, the male population's mean FRP 
value is slightly higher than the female population ( 0.42 for males and 0.39 for females). The results of the t-test also showed significance $(p=0.006)$.

\section{Fire risk perception by age group}

The FPR value by age group reveals that the higher the age, the higher the fire risk perception; however, the result is not statistically significant (' $p$ ' value from ANOVA is 0.061 )). The respondents between 18-24 years old have the lowest risk perception of fire hazard, while the respondents with 59+ years of age have the highest risk perception. The younger group's median value is 0.38 , and the older group had a 0.44 median value on FRP (Figure 6B).

\section{Fire risk perception by education level}

Figure 6C shows that the level of education positively influenced the FRP. Respondents with no formal education to secondary education were more likely to have slightly lower risk perception (median FRP 0.40). Respondents with SSC or HSC levels have slightly higher FRP than the previous group ( 0.42 median FRP value). Consequently, people with a bachelor's or above education had the highest FRP (median FRP value of 0.44). However, the ANOVA does not signify the linearity as the ' $p$ ' value is 0.665 .

\section{Fire risk perception by profession}

Like ERP, the relationship between fire risk perception and profession also has a statistically significant diverse pattern (' $p$ ' value from ANOVA is 0.003). Farmers, private service holders, and government service holders have the highest FRP (median value 0.46). Day wage earners were likely to have the lowest FRP (median value is 0.35 ). This time, housewives also have a low-risk perception of fire hazard (median FRP value is 0.38 ), which is the second-lowest score (Figure 6D).

\section{Fire risk perception by monthly household income}

Figure 6E shows that the higher income group is likely to have higher FRP. However, the lowest income group (income up to 10000 BDT) does not follow the trend. On the other hand, the highest income group (income more than 50000 BDT) has a higher FRP (median value is $0.46)$.

\section{Fire risk perception by household type}

Figure $6 \mathrm{~F}$ uncovers that jhupri, kucha ${ }^{4}$ and semi-pucca ${ }^{4}$ houses likely have the same median FRP value (0.4). However, the mean value is different for these three types of houses. Mean FRP values are $0.37,0.39$, and 0.40 of Jhupri, Kucha, and Semi-Pucca, respectively. The Pucca houses have FRP (mean and median values) 0.43 and 0.44 , respectively. It can be said that there is a similarity in the pattern of FRP with the household types, considering the mean value.

\footnotetext{
4 "Kutcha (temporary); made of mud brick, bamboo, sun-grass, wood and occasionally corrugated iron sheets as roofs. Semi-pucca (semi-permanent); where walls are made partially of bricks, floors are cemented and roofs of corrugated iron sheets" (Source: https://en.banglapedia.org/index.php?title=Housing)
} 

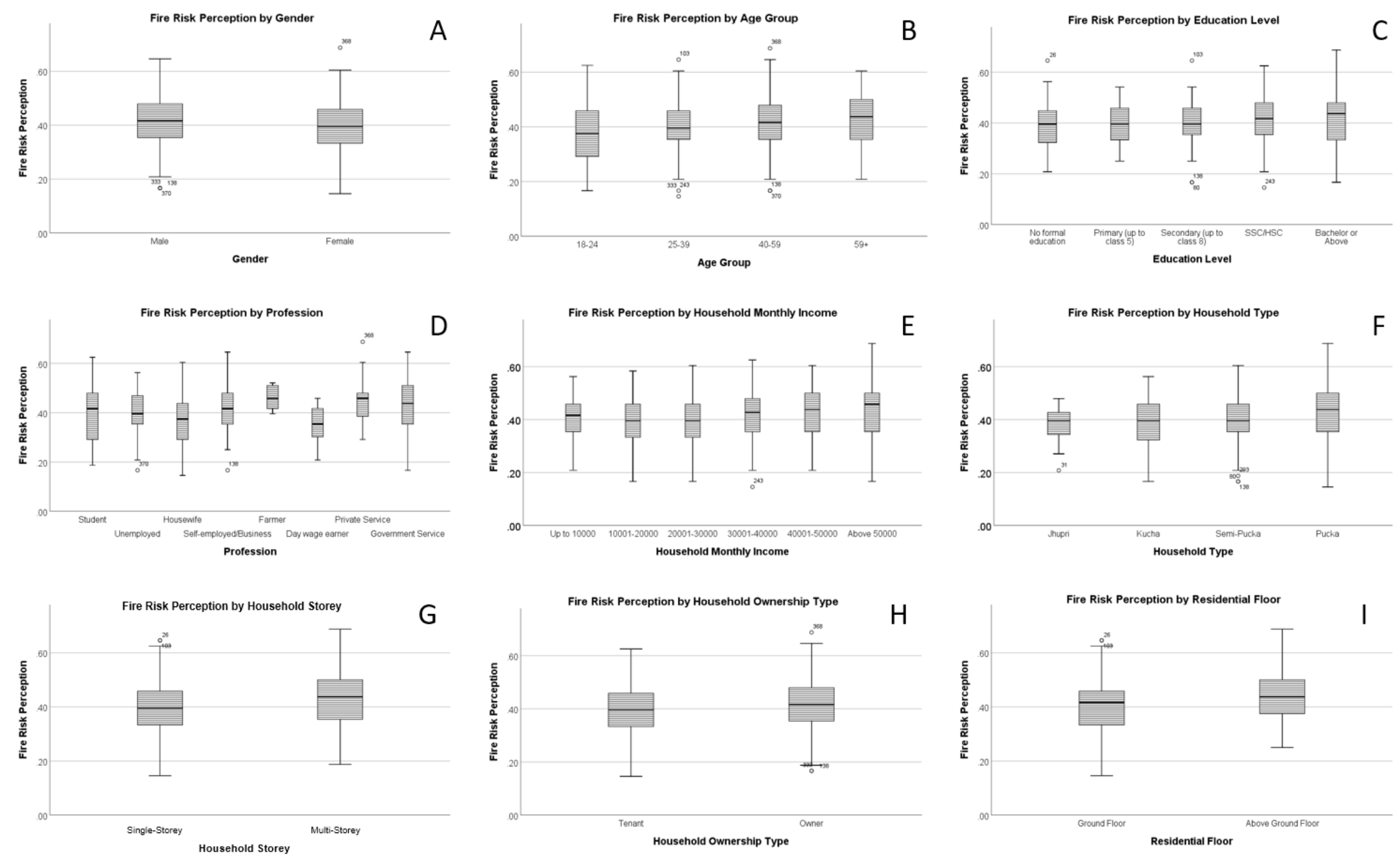

Figure 6. Earthquake risk perception and socio-demographic factors 


\section{Fire risk perception by a household storey}

Figure 6G shows that single-storey household has lower risk perception on fire hazard than the multi-storey households. The mean and median FRP values of multi-storey households are 0.43 and 0.44 , respectively. On the other hand, the mean and median FRP values of singlestorey households are 0.40 and 0.44 , respectively. The observed $p$-value from the t-test is 0.11 .

\section{Fire risk perception by household ownership type}

The FRP by household ownership type shows that the house owners have slightly higher FRP than the tenants. The significance $(p=0.04)$ was observed by the t-test when an equal variance is assumed. Here, FRP values of owners and tenants are 0.40 and 0.42 , respectively (Figure 6H).

\section{Fire risk perception by residential floor}

The residential floor showed a trend in FRP (Figure 6I). The ground floor residents have lower FRP (mean is 0.40 and the median is 0.42 ), where residents from above the ground floor have higher FRP (mean is 0.43 and median is 0.44 ). The results of the t-test also showed the significance $(p=0.04)$ when an equal variance is assumed.

\subsubsection{Fire risk perception dynamics at electoral ward level}

Table 7. Fire risk perception at electoral ward level

\begin{tabular}{ccc}
\hline $\begin{array}{c}\text { Electoral Ward } \\
\text { Number }\end{array}$ & $\begin{array}{c}\text { Fire Risk } \\
\text { Perception Score }\end{array}$ & $\begin{array}{c}\text { Rank } \\
\text { (high to low-risk perception) }\end{array}$ \\
\hline EW-21 & 0.4424 & 1 \\
EW-16 & 0.4360 & 2 \\
EW-30 & 0.4300 & 3 \\
EW-25 & 0.4283 & 4 \\
EW-18 & 0.4247 & 5 \\
EW-22 & 0.4242 & 6 \\
EW-29 & 0.4215 & 7 \\
EW-26 & 0.4179 & 8 \\
EW-17 & 0.4028 & 9 \\
EW-19 & 0.3942 & 10 \\
EW-27 & 0.3896 & 11 \\
EW-20 & 0.3884 & 12 \\
EW-28 & 0.3663 & 13 \\
EW-23 & 0.3662 & 14 \\
EW-24 & 0.3540 & 15 \\
\hline
\end{tabular}


Table 7 shows the fire risk perception dynamics at the electoral ward (EW) level. EW-21 has the highest fire risk perception; the risk perception score is 0.44 . On the other hand, EW24 has the lowest risk perception of a fire hazard; the risk perception score is 0.35 .

\subsubsection{Preparedness on fire hazard at the household and electoral ward level}

Figure 7 shows preparedness for earthquake hazards in $\mathrm{RpCC}$ at the household level. A total of five questions were asked to understand the preparedness for that hazard. The first question was related to checking the condition of the stove/cooker. According to the survey results, $67 \%$ of respondents never check their cooker; they only check if it is broken or not functional (Figure 7A). Moreover, $79 \%$ of people have experienced fire hazards; still, they never check their cooker. However, $13 \%$ of respondents check the condition of the cooker once a year, and the other $12 \%$ check once a month.

On the other hand, $6 \%$ of respondents check the cooker once a week, and the other $2 \%$ check every day before cooking. Respondents from EW-20 have the highest tendency not to check their cooker. $95 \%$ of respondents said they never checked their stove or cooker in this electoral ward, while $5 \%$ of respondents check once a year. In contrast, $32 \%$ of respondents from EW22 said they check the stove or cooker at least once a month as a precaution against fire incidents.

Among the respondents, $65 \%$ never check their electricity connections until any electric lines/switches are broken; however, around $80 \%$ have already experienced fire hazards (Figure 7B). This trend is highest in EW-23; 85\% of respondents of this electoral ward never check their electricity connections. $30 \%$ of respondents check the electricity line at least once a year. Besides, $4 \%$ of respondents check it once a month and $1 \%$ once a week. No respondents were found who check the electricity connections every day.

Figure $7 \mathrm{C}$ reveals that $80 \%$ of the respondents do not have a fire extinguisher at home; the other $20 \%$ do have this. From EW-18, 59\% of respondents had a fire extinguisher. Besides, fire alarms were only used by the respondents of EW-18 and EW-22 (Figure 7D). 18\% of respondents from EW-18 and 11\% from EW-22 has a fire alarm at their house. However, considering all the respondents, only $1 \%$ had a fire alarm at their house.

The last question related to the preparedness on fire hazards was on fire drill participation. $16 \%$ of respondents said they have this experience, while $84 \%$ do not (Figure 7E). EW-25 is far more ahead in this regard; $59 \%$ of respondents participated in a fire drill. On the other hand, the worst-case was seen in EW-24. No respondents from this electoral ward have ever participated in any fire drills. 
How frequently do you check the condition/status of your stove/cooker?

(A)

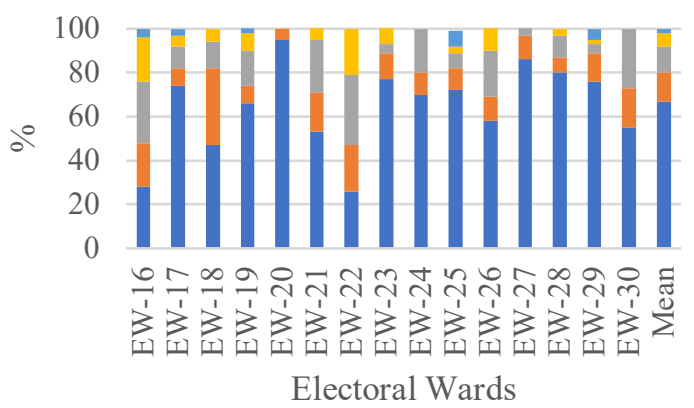

- Never

- Once a month

- Everyday

Do you have a fire extinguisher at your home?

(C)

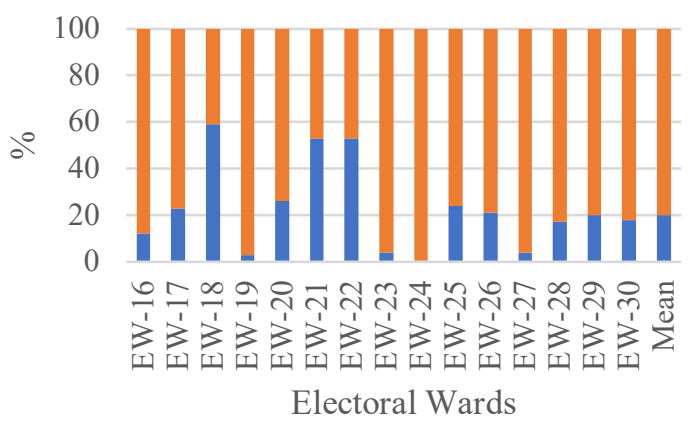

$\square$ Yes $\square$ No
How frequently do you check the electricity line of your house?

(B)

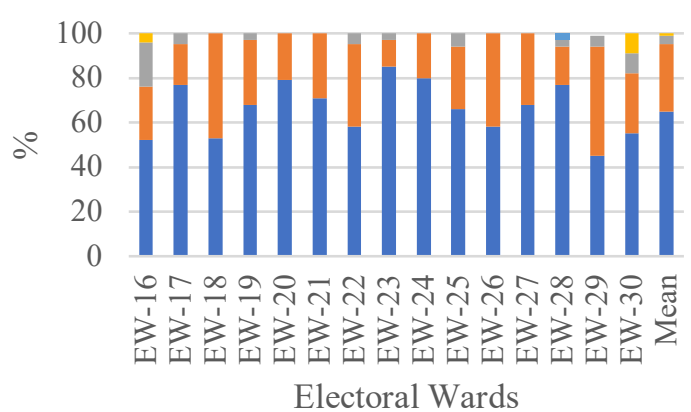

$$
\begin{array}{ll}
\text { - Never } & \text { Once a year } \\
\text { - Once a month } & \text { Once a Week } \\
\text { Everyday } &
\end{array}
$$

Do you have a smoke detector and or fire alarm at your home?

(D)

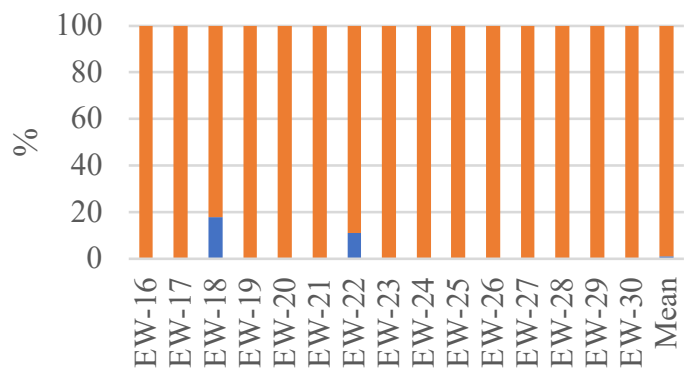

Electoral Wards

- Yes $\square$ No

Have you ever participated in any fire drills?

(E)

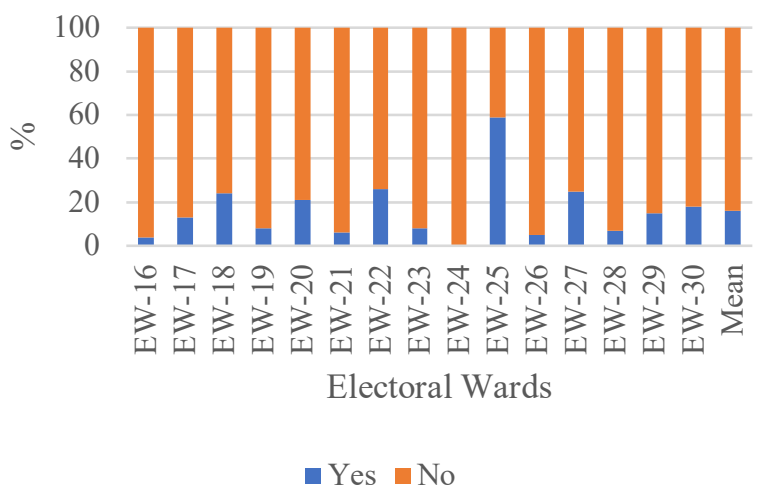

Figure 7. Preparedness on fire hazard (A-E) 


\section{DISCUSSIONS}

\subsection{Risk perception analysis}

In this study, risk perception analysis is focused on earthquake hazards and fire hazards. We looked at three different aspects of the said hazards. Firstly, how risk perception changes with socio-demographic factors; secondly, how the citizen's perception of hazards is spatially distributed; and finally, how the preparedness level of citizens is spatially distributed.

This study's risk perception analysis suggests that women likely have a slightly higher anticipated risk of earthquake hazard than men. Paul \& Bhuiyan (2010) also overserved a similar result for the case of Dhaka City. On the other hand, men likely have a slightly higher anticipated risk of a fire hazard than women. In general, women are more vulnerable than men in any hazard (Rahman et al., 2015) because most Bangladeshi women are unemployed and stay at home most of the time. At the same time, they always try to protect the younger family members, risking their own life during any hazardous events. However, Chan et al. (2018) did not find any statistically significant association between gender and fire risk perception. The field observation reveals that as a family head, men are most likely concerned about financial loss due to any hazards, while women are concerned about the severity of a hazard. Fire hazards could bring more financial loss to men than earthquake hazards, which is why men perceived higher risk in the fire hazard than women.

Risk perception by age group also reveals counterintuitive results. Young people (18-24 years old) have a higher anticipated risk of earthquake hazard than the older age group (59+), while the reverse result was observed for fire risk perception. Experience from the field suggests that the older people have stronger religious beliefs, and they think that an earthquake is 'God's will', and they have nothing to do in this event. As a result, older people anticipated a low risk of earthquake hazards.

Fire risk perception is positively correlated with education level. However, respondents with bachelor's degrees and above were more likely to have a higher perception of earthquake hazard risks. Risk perception by profession also suggests that government employees have higher anticipation than others, which could be due to their higher level of education.

We carried out a correlation analysis to understand the association between sociodemographic variables and risk perception. Four variables were binary variables among the eight socio-demographic factors. Thus, we considered four binary variables for the correlative analysis of risk perception (Table 8). We found from the correlation study that ERP has a very weak positive correlation $(r=0.139)$ with gender. Thus, it seems that the higher the ratio of the female member, the higher the risk perception could be on earthquake hazard. Besides, household ownership type has a very weak negative correlation $(r=-0.113)$ with ERP. That means the tenants could likely have slightly higher ERP than the house owners because they are informed about their house's condition and are less likely to fear an earthquake. At the same time, fire risk perception has a statistically significant correlation with all four binary variables. FRP and gender have a weak negative correlation $(r=-0.140)$; this correlation means that men 
have higher FRP than women. Correlation between FRP and the household storey reveals that FRP increases with the residential height/floors. Besides, ownership also has a slightly positive correlation (0.102) with FRP; the house owners have higher FRP because they are afraid of fire hazards because of immediate financial loss. Finally, the residential floor also has a positive correlation ( $r=0.105)$ with FRP; the higher the residential floor number, the higher FRP of the residents.

Table 8. Pearson correlation matrix of earthquake risk perception and socio-demographic factors

\begin{tabular}{llllll}
\hline & Gender & $\begin{array}{c}\text { Household } \\
\text { Storey }\end{array}$ & $\begin{array}{c}\text { Household } \\
\text { Ownership } \\
\text { Type }\end{array}$ & $\begin{array}{c}\text { Residential } \\
\text { Floor }\end{array}$ & $\begin{array}{c}\text { Earthquake } \\
\text { Risk } \\
\text { Perception }\end{array}$ \\
\hline $\begin{array}{l}\text { Gender } \\
\text { Household Storey }\end{array}$ & 0.007 & 1 & & & \\
$\begin{array}{l}\text { Household Ownership } \\
\text { Type }\end{array}$ & -0.004 & $-.345^{* *}$ & 1 & & \\
$\begin{array}{l}\text { Residential Floor } \\
\text { Earthquake Risk }\end{array}$ & 0.013 & $.663^{* *}$ & $-.329^{* *}$ & 1 & \\
$\begin{array}{l}\text { Perception } \\
\text { Fire Risk Perception }\end{array}$ & $-0.139 * *$ & 0.054 & $-0.113^{*}$ & 0.020 & 1 \\
\hline **. Correlation is significant at the 0.01 level (2-tailed); *. Correlation is significant at the 0.05 level (2-tailed).
\end{tabular}

The spatial pattern of risk perception is distinct for both hazards due to the variation of sociodemographic factors. The abundance of highly educated people and government employees enhances the risk perception at certain electoral wards; on the other hand, the abundance of low-income groups, elderly people, and 'jhupri' houses causes a low-risk perception in some electoral wards. At the same time, there might be other factors related to this result, such as residential density and population density, which could be addressed in any future research.

\subsection{Preparedness}

We already know that RpCC is in earthquake zone 1 and 2 in Bangladesh. Nearly one million people are living in this city. Thousands of new buildings are in the construction phase. As one of the oldest former municipalities of Bangladesh, the core area of RpCC has hundreds of old buildings as well. Considering those, respondent 'I-1' (Table 1) from the local university warned that:

"In every hundred years, we face a severe earthquake. The last one was at Assam in 1897. As Rangpur is in earthquake zone 1 and 2, we are in danger. If it occurs, most of the buildings of the city will collapse. So, building codes need to be maintained properly." 
Nobody can stop the incidence of an earthquake, but sufficient preparedness measures can reduce the vulnerability to this hazard (Paul \& Bhuiyan 2010). Indeed, the overall preparedness on earthquake hazards in RpCC seems insufficient. The earthquake risk perception results show that $53 \%$ of the household do not have any emergency kits. That means they need external help for any medical or evacuation supports. Having the first-aid kits at home is also one of the preparedness measures (Paul \& Bhuiyan 2010). Let us look at the spatial distribution of the availability of the emergency kit. We can see that EW-18 is most vulnerable ( $100 \%$ of surveyed households do not have an emergency or first-aid kit) and EW-20 is most prepared (89\% of surveyed households have an emergency or first-aid kit).

The preparedness results also show that $41 \%$ of the surveyed households do not have an emergency exit to evacuate during a fire emergency. In general, a resident's evacuation behaviour during or after an earthquake event changes with the nearby road layout and the knowledge about a place (Shrestha et al., 2018). So, residents from these households will try to escape from the only door to the nearby roads, which could create a chaotic situation at that moment. From the field experience, we were informed that many house owners lock the main entrance during the night. They do not even give the keys to the tenants. So, if an earthquake event occurs at night, the consequence could be more devastating.

Institutional initiatives on earthquake preparedness are not visible so far here in RpCC. However, one of the officials of RpCC (respondent I-5; Table-1) confirmed that they have a contingency plan to deal with a possible severe earthquake. According to the official:

"We have a contingency plan considering 7-8 scale earthquake. We have used the HAZUS earthquake model to calculate the possible damages. Besides, we have modeled nighttime and daytime scenarios. We have calculated how many people might die and how many people might be injured. Moreover, we have calculated how many buildings could partially or completely collapse. This contingency plan has everything, including healthcare service, evacuation, relief management, security..... everything."

On the other hand, according to field evidence, the preparedness for fire hazards is also not satisfactory. $80 \%$ of households do not have a fire extinguisher, and $84 \%$ of respondents did not ever participate in a fire drill. Moreover, $99 \%$ of the households do not have a smoke detector. Notably, a smoke detector can protect the life of the residents by alerting the residence, and a fire extinguisher can reduce the damage of a residential fire hazard (Stumpf, Knuth, Kietzmann, \& Schmidt 2017).

In RpCC, Fire Service and Civil Defence (FSCD), Rangpur plays a significant role in preparing and mitigating fire hazards. Their enthusiasm, hard work, and professionalism seem very high from the field experience and observations. The FSCD has identified several causes of fire hazards in RpCC. One of the officials from FSCD (respondent I-4; Table 1) said:

"We identified a total of 17/18 reasons behind fire hazard. Among them, the biggest reason is electrical disturbances. In addition, the blast of gas cylinders is another reason. Besides, the use of anti-mosquito coils, throwing of cigarette filters, and the use of poly bags play a great role in the occurrence of fire hazard." 
Despite the hard work of the FSCD members, several issues make their efforts more challenging. Considering this, we asked the previous spokesman about the difficulties of FSCD during an event, and he (respondent I-4; Table 1) replied:

"Firstly, the narrowness of the roads. The fire service team cannot reach the location of the events properly. Traffic jam due to auto-rickshaw also creates a barrier to reach the location. There is a lack of water sources; most sources are filled up for residential or commercial purposes. Especially, the 'Shyamashundari Canal' is almost destroyed. These could play a vital role. We need to set fire hydrants like developed countries; it will be beneficial in the long term to fight the fire. Besides, too many curious people create an extra barrier during a fire accident. It is challenging to control curious people."

He (respondent I-4; Table 1) also emphasized that:

"More than 250 high-rise buildings (above six floors) are planned for construction and have approval from the city corporation, but we do not have sufficient and suitable equipment supports for those buildings. We need different vehicles (for example, TTI's) to fight at a high-rise building. We are expecting to get those soon from the government."

The above remarks depict that the electrical disturbances, the blast of a gas cylinder, flammable anti-mosquito coils, and cigarette filters are the major causes of fire hazards in the RpCC area. Narrow roads and traffic jams are the main barriers to reach the place of a fire accident. Besides, FSCD faces difficulty obtaining water sources during the fire-fighting because water sources are used for other purposes, and there is an absence of fire hydrants in RpCC. Furthermore, FSCD needs proper equipment to protect more than 250 high-rise buildings in any possible fire events. Besides, FSCD should arrange more fire drills across the city.

\subsection{Planning guidelines and policy interventions}

According to the RpCC master plan, the city corporation should establish City Disaster Management Committee (CDMC) and other supporting standing committees (LGED 2014). These committees should have been formulating provisions for pre-disaster risk mitigation and post-disaster recovery program. Nevertheless, this committee has not been formed yet. After establishing the committee, we suggest that this study's results could be considered for planning and policy interventions to reduce the risk of different hazards based on the local context's need.

Based on the evidence from this study, we suggest that RpCC needs specific planning guidelines and policy interventions to reduce the risk of earthquake and fire hazards. Widening the roads and ensuring accessibility of water availability are critical priority areas of the building bylaws for earthquake and fire safety measures. Though RpCC Master Plan has plans and provisions for wide road and building safety (LGED 2014), neither plans nor provisions are fully functional. 
The spatial variation of fire risk perception and preparedness in the electoral wards can assist the authority in initiating area-based awareness programs. The highest priority for awareness campaigns should be given to the EWs with very low-risk perception and preparedness. Apart from that, an emergency exit in every household should be obligatory; it will help the residents to evacuate the residential building quickly in the occurrence of both hazards. Moreover, using a smoke detector and fire extinguisher should be mandatory for every household of RpCC.

We also suggest that preparedness for both hazards needs cooperation and collaboration among citizens and different authorities. The local university could provide academic supports to the respective authorities. Moreover, as a parent organization of the city, the RpCC needs to increase awareness programs significantly.

\section{KEY FINDINGS, PLANNING GUIDELINES, AND CONCLUSION}

Key findings are as follows, based on the results and discussions of the study:

Earthquake risk perception (ERP) has significant relations (very weak) with gender and household ownership.

$\square$ Fire risk perception (FRP) has significant relations (very weak) with gender, household storey, and residential floor.

$\square$ Moreover, ERP is higher in women, and FRP is higher in men. Awareness programs could be initiated considering the above facts. At the same time, EW-18 needs much attention to preparedness measures.

EW-16 could be a model electoral ward considering both types of risk perception and preparedness.

We also suggest a few planning guidelines and policy interventions for disaster resilience in Rangpur city. They are:

Widen roads.

Ensure water availability /fire hydrants.

$\square$ Reenforce the building bylaws.

Enhance the capacity of the Fire Service and Civil Defence (FSCD) (as 250 high-rise buildings are under construction).

Inhibit the construction of high-rise buildings until the FSCD achieves the ability.

$\square$ Ensure mandatory emergency exit, smoke detectors, and fire alarms in every house.

Finally, this study uncovered many aspects of risk perception and preparedness at the household and electoral ward levels. The study results reveal that gender, social status, and economic status influence citizens' risk perception. At the same time, risk perception changes 
at the electoral ward level as well. The government and concerned authorities should consider these planning and policy formulation issues, emphasizing the city's disaster resilience. However, there were a few limitations to this study. Maintaining an equal ratio for single-storey and multi-storey buildings was not possible during the questionnaire survey due to the accessibility issue. Residents from the upper floors were not reachable due to the lock at the main entrance. Moreover, they do not feel safe opening the gate and answering the questionnaire. Another limitation of this study is that the questions (for risk perception analysis) were formulated based on previous literature. However, there was a little number of literature (Islam \& Adri 2008; Ministry of Disaster Management and Relief 2015; Paul \& Bhuiyan 2010; Rahman et al. 2015) available in the context of Bangladesh. For future research, we suggest that multiple regression analysis could be carried out to examine the relationships between risk perceptions and socio-demographic attributes for predicting associated risk factors. Moreover, the relationship between the perception of earthquake and fire hazards has not been done in this study. This relationship could be analyzed in future studies composing the correlation analyses in future possibilities, effect on personal life and family, perceived risk of property damage, perceived risk of death, and fearfulness of the earthquake and fire perceptions.

\section{REFERENCES}

Ali, M. H. (1998). Earthquake Database and Seismic Zonning of Bangladesh. INCEDE Report (Vol. 11). Bangkok. Retrieved from http://cidbimena.desastres.hn/pdf/eng/doc122 94/doc12294-contenido.pdf

Appleby-Arnold, S., Brockdor, N., Jakovljev, I., \& Zdravković, S. (2018). Applying cultural values to encourage disaster preparedness: Lessons from a low-hazard country, 31, 37-44. https://doi.org/10.1016/j.ijdrr.2018.04.015

Burke, J., \& Hammadi, S. (2012, November 25). Bangladesh textile factory fire leaves more than 100 dead | World news | The Guardian. Retrieved September 15, 2019, from https://www.theguardian.com/world/2012/nov/25/bangladesh-textile-factory-fire

Chan, E. Y. Y., Lam, H. C. Y., Chung, P. P. W., Huang, Z., Yung, T. K. C., Ling, K. W. K., ... Chiu, C. P. (2018). Risk Perception and Knowledge in Fire Risk Reduction in a Dong Minority Rural Village in China: A Health-EDRM Education Intervention Study. International Journal of Disaster Risk Science, 9, 306-318. https://doi.org/10.1007/s13753-018-0181-X

Fernandez, G., Tun, A. M., Okazaki, K., Zaw, S. H., \& Kyaw, K. (2018). Factors influencing fire, earthquake, and cyclone risk perception in Yangon, Myanmar. International Journal of Disaster Risk Reduction, 28, 140-149. https://doi.org/10.1016/j.ijdrr.2018.02.028

Islam, M. M., \& Adri, N. (2008). Fire Hazard Management of Dhaka City: Addressing Issues Relating to Institutional Capacity and Public Perception. Jahangirnagar Planning Review, 6(6), 57-68.

Jones, A. (2010, January 4). Dhaka fire 2010 kills at least 77, injures $100 \mid$ World news |The Guardian. Retrieved September 15, 2019, from https://www.theguardian.com/world/201 0/jun/04/dhaka-fire-deaths 
Kung, Y.-W., \& Chen, S.-H. (2012). Perception of Earthquake Risk in Taiwan: Effects of Gender and Past Earthquake Experience. Risk Analysis, 32(9), 1535-1546. https://doi.org/10.1111/j.1539-6924.2011.01760.x

LGED. (2014). Rangpur City Master Plan: 2014-2033. Retrieved from https://www.rpcc.go v.bd/city-plan/Rangpur_city corporation_Master_Plan_Final_Report.pdf

Ministry of Disaster Management and Relief. (2015). Atlas: Seismic Risk Assessment in Bangladesh for Bogra, Dinajpur, Mymensingh, Rajshahi, Rangpur and Tangail City Corporation / Paurashava Areas, Bangladesh. (S. M. Haque, Ed.), ATLAS, Ministry of Disaster Management and Relief. Retrieved from https:/www.undp.org/content/dam/ba ngladesh/docs/Publications/Pub2016/Seismic\%20Risk\%20Assessment\%20in\%20Bangl adesh.pdf

Norton, J., Atun, F., \& Dandoulaki, M. (2015). Exploring Issues Limiting the Use of Knowledge in Disaster Risk Reduction. Tema. Journal of Land Use, Mobility and Environment, (Special Issue ECCA), 135-154. https://doi.org/10.6092/1970-9870/3032

Paul, B. K., \& Bhuiyan, R. H. (2010). Urban earthquake hazard: perceived seismic risk and preparedness in Dhaka City, Bangladesh. Disasters, 34(2), 337-359. https://doi.org/10.1111/j.1467-7717.2009.01132.x

Rahman, N., Ansary, M. A., \& Islam, I. (2015). GIS based mapping of vulnerability to earthquake and fire hazard in Dhaka city, Bangladesh. International Journal of Disaster Risk Reduction, 13, 291-300. https://doi.org/10.1016/j.ijdrr.2015.07.003

Rahman, M. Z. (2020). Relationship Between Multiple Deprivation and Disaster Risk Perception in Rangpur City, Bangladesh. (Master's thesis, Faculty of Geo-Information Science and Earth Observation, University of Twente, Enschede, Netherlands). Retrieved from http://essay.utwente.n1/85174/

RpCC. (2019). Introduction to Rangpur City Corporation. Retrieved September 15, 2019, from https://rpcc.portal.gov.bd/site/page/0046cdb2-b2a0-499e-b4cf-1c1c0e89a49d

Safi, M. (2019, February 21). Dhaka fire that killed 80 raises questions over chemical stores | World news | The Guardian. Retrieved September 15, 2019, from https://www.theguardian.com/world/2019/feb/21/dhaka-fire-more-than-50-die-inapartments-used-as-chemical-store

Shrestha, S. R., Sliuzas, R., \& Kuffer, M. (2018). Open spaces and risk perception in postearthquake Kathmandu city. Applied Geography, 93, 81-91. https://doi.org/10.1016/j.apgeog.2018.02.016

Stumpf, K., Knuth, D., Kietzmann, D., \& Schmidt, S. (2017). Adoption of fire prevention measures - Predictors in a representative German sample. Safety Science, 94, 94-102. https://doi.org/10.1016/j.ssci.2016.12.023

Sullivan-Wiley, K. A. S., \& Gianotti, A. G. S. (2017). Risk Perception in a Multi-Hazard Environment. World Development, 97, 138-152. https://doi.org/10.1016/j.worlddev.201 7.04.002

Wachinger, G., Renn, O., Begg, C., \& Kuhlicke, C. (2013). The risk perception paradoximplications for governance and communication of natural hazards. Risk Analysis, 33(6), 1049-1065. https://doi.org/10.1111/j.1539-6924.2012.01942.x 